\title{
Comparison of big cat food habits in the Amazon piedmont forest in two Bolivian protected areas
}

\author{
Cecilia Flores-Turdera ${ }^{1 *}$, Guido Ayala ${ }^{1}$, María Viscarra ${ }^{1}$, and Robert Wallace ${ }^{1,2}$ \\ ${ }^{1}$ Wildlife Conservation Society. Calle Gabino Villanueva 340, La Paz. Bolivia. Email: cflorest@wcs.org (CFT) gayala@wcs.org (GA) \\ mviscarra@wcs.org (MV). \\ ${ }^{2}$ Wildlife Conservation Society. Bronx, New York 10460. New York, United States. Email: rwallace@wcs.org (RW). \\ ${ }^{*}$ Corresponding author
}

The feeding habits of jaguar (Panthera onca) and puma (Puma concolor) were studied in the lower Tuichi, Hondo (PNANMI Madidi) and Quiquibey (RB Pilón Lajas) river valleys. A total of 122 large felid scats were collected and identified by an experienced local guide, with identifications later confirmed by morphometry. Of this total, 54 were also identified using associated tracks. For jaguar, prey species richness was 25 species considering all scats and 20 species only considering those scats associated with tracks. For puma, 28 and 22 prey species were obtained, respectively. The results indicate that there is low trophic niche overlap between both cats ( 0.46 and 0.44 respectively). The breadth of the trophic niche indicates that the jaguar is more specialized in its diet ( 0.28 and 0.42 respectively), mainly due to the high consumption of the white-lipped peccary (Tayassu pecari), which contributes significantly to jaguar prey biomass. The puma has a more generalist tendency ( 0.56 and 0.58 respectively), with the spotted paca (Cuniculus paca) the most frequently consumed prey and also contributing the most biomass. Despite the fact that both felines share most of their prey, jaguar and puma differ in the frequency of prey consumption.

Se estudiaron los hábitos alimentarios de jaguar (Panthera onca) y puma (Puma concolor) en áreas cercanas a los ríos Tuichi, Hondo (PNANMI Madidi) y Quiquibey (RB Pilón Lajas). Se recolectaron un total de 122 excretas con la ayuda de un guía de campo experimentado en identificación de heces de ambos felinos, mismas que fueron confirmadas mediante morfometría. De este total, 54 fueron identificadas además mediante huellas asociadas, observando que los resultados muestran similitud con ambos análisis. Se obtuvo una riqueza de especies para jaguar de 25 presas con el total de heces y 20 presas con el total de heces asociadas a huellas. Para puma se obtuvo 28 y 22 presas respectivamente en ambos análisis. Los resultados indican que hay poco solapamiento de nicho trófico entre ambos felinos ( 0.46 y 0.44 respectivamente), pues los resultados de amplitud de nicho trófico indican que el jaguar es más especialista en su dieta ( 0.28 y 0.42 respectivamente), principalmente por el elevado consumo de Tayassu pecari, el cual aportó más a la biomasa consumida por este felino. En tanto el puma se muestra más generalista ( 0.56 y 0.58 respectivamente), donde la presa consumida con mayor frecuencia y la que aportó más a su biomasa fue Cuniculus paca. A pesar de que ambos felinos comparten la mayor parte de sus presas, el jaguar consume unas con más frecuencia y el puma otras.

Keywords: biomass; diet; PNANMI Madidi; RBTCO Pilón Lajas; trophic niche.

(C) 2021 Asociación Mexicana de Mastozoología, www.mastozoologiamexicana.org

\section{Introduction}

The jaguar (Panthera onca) and the puma (Puma concolor) are the largest felids in the Americas, and are sympatric in much of the Neotropics (Sunquist and Sunquist 1989; Farrell et al. 2000). Both are strict carnivores (Kitchener 1991), and knowledge of their diet help inform conservation strategies (Farrell et al. 2000), since food plays a fundamental role in evolutionary behavior of predators (Ramalho and Magnusson 2009). In addition, prey availability is one of the main factors that determines the presence, behavior and ecology of predators in the ecosystems where they live, and predator-prey relationships can influence community dynamics, maintaining the balance of an ecosystem (Sunquist and Sunquist 1989; Aranda 2000; Ramalho and Magnusson 2009; Chumacero and Sainoz 2010).

Studies on the diet of both species in South America show the capture of larger prey by jaguar, and medium to small prey by puma (Schaller and Crawchaw 1980; Emmons 1987; Maxit 2001; Crawshaw and Quigley 2002; Leite et al. 2002; Scognamillo et al. 2003; Caselli de Azevedo 2008). However, studies in Central America and North America report a greater consumption of larger prey by puma, espe- cially deer species (Nuñez et al. 2000; Novack et al. 2005; Hernández 2008; Gómez 2010).

In this study we report on jaguar and puma food habits in the Madidi National Park and Natural Area of Integrated Management Area (PNANMI Madidi) and the Pilón Lajas Biosphere Reserve (RBTCO Pilón Lajas) in northwestern Bolivia, including trophic niche breadth, relative biomass consumed from the prey by each felid, and trophic niche overlap between the species. This study aims to improve our understanding of the diet of both cats at this study area and contribute towards actions for their protection and broader conservation strategies for the protected areas. It also seeks to obtain a greater understanding of variations in diet of both cats within their distribution, as compared to similar works at different study sites.

\section{Methods}

Study Area. The study was conducted in the Amazon piedmont forest along the beaches and in the riverine forests of the Tuichi, Hondo and Quiquibey rivers, tributaries of the Beni River (De la Quintana 2005). The first two riv- 
ers are found in the Franz Tamayo Province of the La Paz Department within PNANMI Madidi (De la Quintana 2005), and the third river is within the Ballivián Province of the Beni Department within RBTCO Pilón Lajas (Figure 1). The average elevation is around 251 masl, annual rainfall oscillates between 1,300 to 2,444 $\mathrm{mm}$, and temperature averages $24.9^{\circ} \mathrm{C}$ (Navarro and Maldonado 2002).

Forests at the study site are a mixture of riverine varzea and terre firme primary forests on the alluvial fans between 300 and $500 \mathrm{~m}$, both with tall emergent trees (Identidad Madidi and SERNAP 2019). The vegetation is characterized by a great diversity of palm trees, with the most representative genera Acrocomia sp., Allagoptera sp., Astrocaryum sp., Attalea sp., Bactris sp., Chamaedorea sp., Desmoncus sp., Geonoma sp. Socratea sp., Syagrus sp., Scheelea sp., Jessenia sp. (Wallace et al. 2003; Paniagua-Zambrana 2005), as well as families of vascular plants such as Pteridaceae, Sapindaceae, Lauraceae, Bignonaceae, Polypoidaceae, Melastomataceae, Rubiaceae, and Fabaceae (Jorgensen et al. 2005).

According to the field survey conducted by the scientific expedition Identidad Madidi in 2016, more than 428 species of vertebrates have been registered along the Hondo river, including 26 medium and large-sized mammals (Identidad
Madidi and SERNAP 2019). The mammalian fauna of the area includes the following potential prey species for jaguar (Panthera onca) and puma (Puma concolor): tayra (Eira barbara), brown-nosed coati (Nasua nasua), crab-eating raccoon (Procyon cancrivorus), lowland tapir (Tapirus terrestris), white-lipped peccary (Tayassu pecari), collared peccary (Pecari tajacu), red brocket deer (Mazama americana), capybara (Hydrochoerus hydrochaeris), agoutis (Dasyprocta spp.), paca (Cuniculus paca), southern tamandua (Tamandua tetradactyla), black-eared opossum (Didelphis marsupialis) and forest rabbit (Sylvilagus brasiliensis) (Ríos-Uzeda et al. 2001; Gómez et al. 2005; Identidad Madidi and SERNAP 2019).

Fieldwork. Fieldwork was carried out between July and October 2008, with 62 days of sampling effort at sites near the Tuichi, Hondo and Quiquibey rivers, intensively searching beaches, streams, old river stretches and riparian forests which are the habitats with the highest probability of finding jaguar and puma scats. Searches were also carried out along 3 to $5 \mathrm{~km}$ transects within terra firme forest. The collected scats were identified using morphometry and local guide experience. All encountered scats were measured for diameter and length, to compare with previous descriptions (Aranda 2000; Chame 2003). In some cases, scats were identified with scat morphometry, as well as associated tracks,

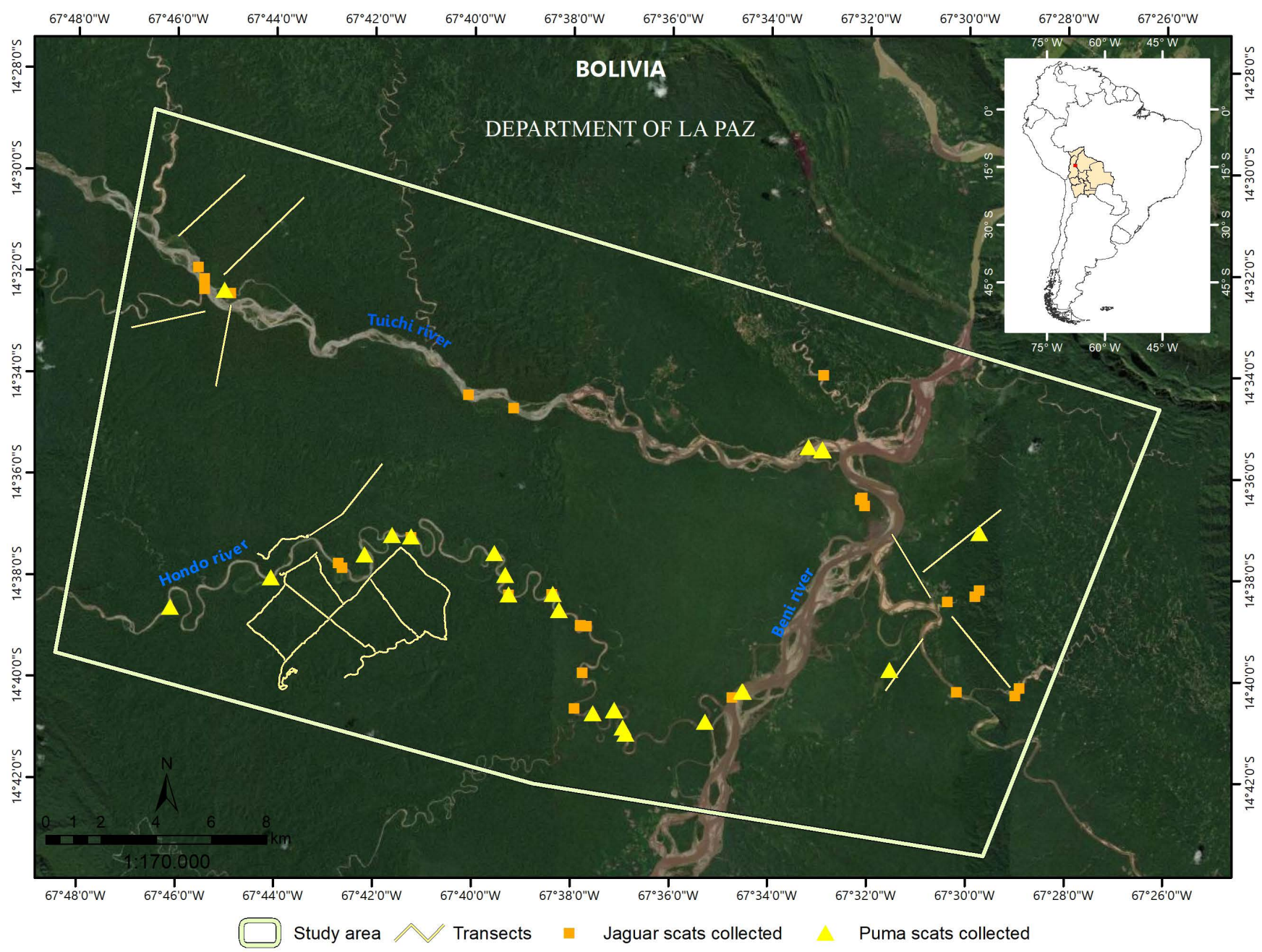

Figure 1. Study area for jaguar and puma diet in the PNANMI Madidi and RBTCO Pilón Lajas, Bolivia. 
using track descriptions from De Angelo et al. (2008). More than $85 \%$ of collected scats were fresh, and even old scats retained their morphological characteristics, allowing measurements for their identification. Each scat was collected in paper envelopes labeled with the date, site, coordinates, habitat and species. All samples were placed in the shade until sent to La Paz city for subsequent laboratory analysis.

Laboratory work. The scat samples were dried at room temperature before separating food items. For mammals, species identification was performed using teeth morphometry, and mainly hair descriptions, analyzing: A) Morphological characteristics, considering the size, color and thickness of the hair, and comparing with the Wildlife Conservation Society catalog of Bolivian mammal hairs (Viscarra et al. 2010). B) Cuticle patterns, the hairs were cleaned and stamped in a thin layer of transparent nail polish onto a slide, then dried and removed with a tweezer, observed under a microscope, considering the pattern, shape and size of the cuticles (Short 1978; Chehébar and Martin 1989; Fernández and Rossi 1998; Vásquez et al. 2000; Quadros and Monteiro-Filho 2006; Zafarina and Panneerchelvan 2009). C) Core patterns, following the methodology proposed by Fernández and Rossi (1998) and Tavera (2006), with modifications and adaptations standardizing the methodology to be applied to all types of hair thickness. The hairs were dipped in a mixture of $50 \%$ sulfuric acid (98\%) and $50 \%$ alcohol (96\%) for 48 hours, until the cuticles were shed. Subsequently, the hairs were washed with water. Finally, they were moistened with a drop of water and placed on a slide for identification, taking note of the shape, diameter and width of the marrow.

Data Analysis. The Frequency of Occurrence (FO \%) and the Relative Biomass Consumption (RBC of the prey were calculated; Ackerman et al. 1984). The Relative Biomass Consumption (RBC \%) of each prey was calculated for each cats' diet according to the live weight of the prey species, representing the importance of a prey type in the diet in proportion to its contribution (Farrell et al. 2000). Food items whose species identity was unknown were removed from the RBC $\%$ analyses due to undetermined weight.

An analysis by prey size category was carried out: large prey (> $15 \mathrm{~kg}$ ), medium prey (from 1 to $15 \mathrm{~kg}$ ) and small prey $(<1 \mathrm{~kg})$, following the classifications of Iriarte et al. (1990), Taber et al. (1997), Scognamillo et al. (2003) and Paviolo (2010). The trophic niche overlap between both cats was calculated using the Pianka Index (Pianka 1973), and the trophic niche width for each feline using the Levins Index (Levins 1968). We performed these analyses using the entire scat sample for each large felid, as well as using only those scats associated with clearly identifiable tracks.

To determine whether jaguar and puma prey consumption was influenced by prey abundance, a linear regression analysis was performed between the relative abundance of prey species (events/100 camera trap night) at the study site during the same year (Ayala and Viscarra 2009) and the
FO $\%$ of the prey consumed in this study for total scats collected, and scats associated with tracks, evaluating the significance of ANOVA $(F \leq 0.05)$ and Pearson $R^{2}$.

For this analysis, the original data were previously transformed to natural logarithms, evaluating the normality of the data with Shapiro-Wilk $(P \leq 0.05)$. The FO \% and prey abundance variables for the total of collected scats reported in the zone for jaguar (abundance: $\mathrm{W}=0.9327, \mathrm{P}=$ $0.3327 ; \mathrm{FO} \%: \mathrm{W}=0.8897, \mathrm{P}=0.08$ ) and puma (abundance: $\mathrm{W}=0.9398, \mathrm{P}=0.4944 ; \mathrm{FO} \%: \mathrm{W}=0.9546, \mathrm{P}=0.7054$ ) were normal. The FO $\%$ and prey abundance variables for scats associated with tracks for puma (abundance: $W=0.9398, P$ $=0.4949 ; \mathrm{FO} \%: \mathrm{W}=0.9518, \mathrm{P}=0.6633$ ) were also normal. For jaguar scats associated with tracks the prey abundance variable $(\mathrm{W}=0.9327 \mathrm{P}=0.3327$ ) was normal, but for $\mathrm{FO} \%$ (FO \%: $\mathrm{W}=0.8241 \mathrm{P}=0.0134$ ) was not normal. These analyses were performed with the JMP Program version 7.0.1. (SAS Institute Inc. 2007).

\section{Results}

A total of 122 large felid scats were collected: 66 jaguar and 56 puma scats. Of the collected scats 68 were identified using morphometry and local guide experience, and 54 were identified with morphometry and associated tracks. The totality of collected jaguar scats included items from 25 species (Table 1), with a higher consumption of larger prey (55\%), mainly artiodactyls, and especially the whitelipped peccary (Tayassu pecari; $28 \%$ ). Using only scats associated with tracks, we detected 20 prey species, again with T. pecari the most frequently consumed prey ( $27 \%)$. For puma (Table 1), items from 28 species were identified, with a higher consumption ( $56 \%$ ) of medium-sized prey, such as rodents, especially the paca (Cuniculus paca; $14 \%$ ). Using only scats associated with tracks, we detected 22 prey species, again with $C$. paca still the most frequently consumed prey $(16 \%)$.

Considering all collected scats, six main prey species were reported for jaguar (T. pecari, Pecari tajacu, Dasyprocta spp., Mazama americana, Cuniculus paca and Nasua nasua), representing $61 \%$ of their total diet (Table 1). For puma, seven main prey were reported (C. paca, Didelphidae, Echimyidae, P. tajacu, N. nasua, Sylvilagus brasiliensis and Didelphis marsupialis), representing $54 \%$ of their diet (Table 1). For scats associated with tracks, four main species were reported for jaguar (T. pecari, P. tajacu, Dasyprocta spp. and $N$. nasua), representing $51 \%$ of their diet. For puma, and five main species for pumas (C. paca, Didelphis marsupialis, Didelphidae, N. nasua and Echimyidae), representing $51 \%$ of their diet.

The RBC \% analysis, found that the two peccaries, $T$. pecari (37\%) and P. tajacu ( $22 \%)$, contributed the most to the biomass of jaguar diet. Although Tapirus terrestris did not have a high FO \%, it was the second most important biomass contribution towards jaguar diet (Table 2). Using only those scats associated with tracks this analysis indicated that T. pecari (33\%), T. terrestris (16\%) and P. tajacu 
(11\%) were the three most important prey species for jaguar. For puma, C. paca (18\%) and P. tajacu (11\%) were the prey that contributed the most biomass to diet (Table 2), and using only those scats associated with tracks $C$. paca (20\%), D. marsupialis (11 \%) and P. tajacu (10\%) were the most important prey.

Regarding the breadth of the trophic niche, a more specialized trend was observed for jaguar (0.28), and a more general trend for puma (0.56). There was a relatively low

Table 1. Prey species richness for jaguar and puma in PNANMI Madidi and RBTCO Pilón Lajas, Bolivia.

\begin{tabular}{|c|c|c|c|c|c|c|c|c|}
\hline \multirow[b]{3}{*}{ Prey } & \multicolumn{4}{|c|}{ All scats } & \multicolumn{4}{|c|}{ Scats with tracks } \\
\hline & \multicolumn{2}{|c|}{ Jaguar } & \multicolumn{2}{|c|}{ Puma } & \multicolumn{2}{|c|}{ Jaguar } & \multicolumn{2}{|c|}{ Puma } \\
\hline & No & FO\% & No & FO\% & No & FO \% & No & FO \% \\
\hline \multicolumn{9}{|l|}{ Large prey } \\
\hline Tayassu pecari & 31 & 28 & 4 & 2 & 13 & 27 & 3 & 4 \\
\hline Pecari tajacu & 20 & 18 & 11 & 7 & 5 & 10 & 5 & 6 \\
\hline Mazama americana & 5 & 5 & 5 & 3 & 2 & 4 & 2 & 3 \\
\hline Tapirus terrestris & 2 & 2 & & & 2 & 4 & & \\
\hline Hydrochoerus hydrochaeris & 2 & 2 & & & 1 & 2 & & \\
\hline Myrmecophaga tridactyla & 1 & 1 & & & 1 & 2 & & \\
\hline Caiman yacare & & & 1 & 1 & & & & \\
\hline \multicolumn{9}{|l|}{ Medium-sized prey } \\
\hline Dasyprocta spp. & 6 & 5 & 5 & 3 & 4 & 8 & 1 & 1 \\
\hline Cuniculus paca & 5 & 5 & 24 & 14 & 1 & 2 & 13 & 16 \\
\hline Nasua nasua & 4 & 4 & 10 & 6 & 3 & 6 & 6 & 8 \\
\hline Ateles chamek & 2 & 2 & 3 & 2 & 2 & 4 & 1 & 1 \\
\hline Sylvilagus brasiliensis & 2 & 2 & 10 & 6 & 1 & 2 & 5 & 6 \\
\hline Didelphis marsupialis & 2 & 2 & 10 & 6 & 1 & 2 & 8 & 10 \\
\hline Procyon cancrivorus & 1 & 1 & 8 & 5 & 1 & 2 & 3 & 4 \\
\hline Eira barbara & 1 & 1 & 4 & 2 & 1 & 2 & 3 & 4 \\
\hline Potos flavus & 1 & 1 & 1 & 1 & & & 1 & 1 \\
\hline Echimyidae & 1 & 1 & 12 & 7 & 1 & 2 & 6 & 8 \\
\hline Alouatta sara & & & 1 & 1 & & & & \\
\hline Tamandua tetradactyla & & & 1 & 1 & & & 1 & 1 \\
\hline Bradypus variegatus & & & 1 & 1 & & & 1 & 1 \\
\hline Galictis vittata & & & 3 & 2 & & & & \\
\hline \multicolumn{9}{|l|}{ Small prey } \\
\hline Sciurus spadiceus & 3 & 3 & 7 & 4 & 2 & 4 & 3 & 4 \\
\hline Ameiva sp. & 1 & 1 & 3 & 2 & 1 & 2 & 1 & 1 \\
\hline \multicolumn{9}{|l|}{ Unidetified prey } \\
\hline Plants & 9 & 8 & 5 & 3 & 3 & 6 & 4 & 5 \\
\hline Unidentified rodents & 3 & 3 & 5 & 3 & 1 & 2 & 2 & 3 \\
\hline Unidentified birds & 3 & 3 & 8 & 5 & 2 & 4 & 2 & 3 \\
\hline Unidentified mammals & 2 & 2 & 5 & 3 & & & & \\
\hline Unidentified reptiles & 2 & 2 & 2 & 1 & & & & \\
\hline Didelphidae & 1 & 1 & 14 & 8 & & & 7 & 9 \\
\hline Colubridae & 1 & 1 & 2 & 1 & & & & \\
\hline Hoplocercidae & & & 1 & 1 & & & 1 & 1 \\
\hline Total occurrences & 111 & & 166 & & 48 & & 79 & \\
\hline Total items & 25 & & 28 & & 20 & & 22 & \\
\hline Total scats & 66 & & 56 & & 28 & & 26 & \\
\hline
\end{tabular}

$\mathrm{N}^{0}=$ Number of occasions in which a prey was registered in jaguar and puma scats; $\mathrm{FO} \%=$ Percentage of the Frequency of Occurrence of each consumed prey. trophic niche overlap between both cats (0.46). Using only scats associated with tracks, the breadth of the trophic niche for jaguar is 0.42 and for puma is 0.58 , underlining a more specialized diet for jaguar as compared to puma. The trophic niche overlap was similar using only scats associated with tracks (0.44).

The FO \% of total scats collected and the relative abundance of prey (Ayala and Viscarra 2009) for jaguar and puma are presented in Tables 3 and 4, respectively. Considering all collected scats, the linear regressions for FO \% and prey abundance, showed significant positive relationships for both jaguar $\left(r^{2}=43 \% ; F=0.0104\right)$ and puma $\left(r^{2}=44 \% ; F=\right.$ 0.0179; Figure 2). For puma, the linear regression between FO \% of scats associated with tracks and prey abundance was not significant $\left(r^{2}=25 \% ; F=0.0963\right)$.

\section{Discussion}

In this study, jaguar and puma foraging behavior responded to prey availability, with the most abundant prey at our study site contributing most to their diets. We recorded that

a

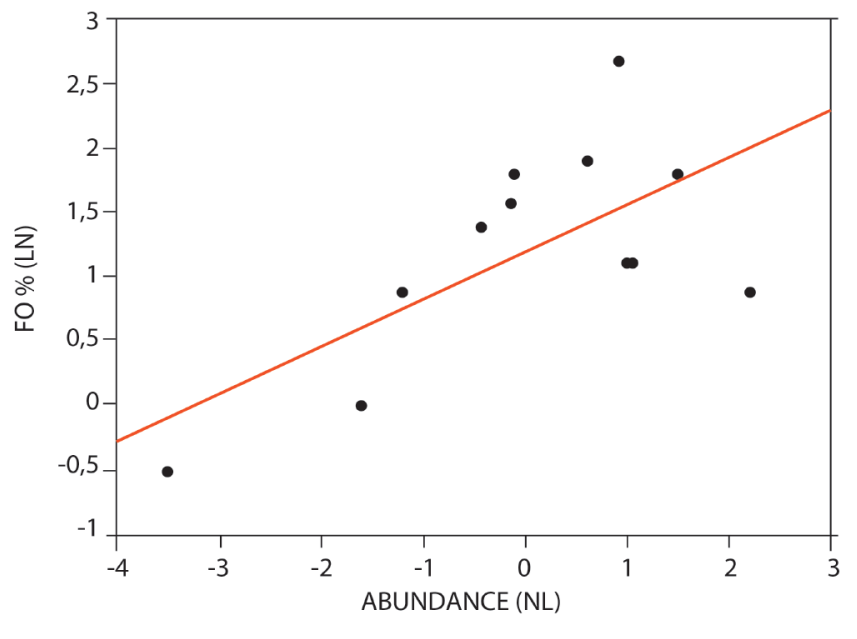

b

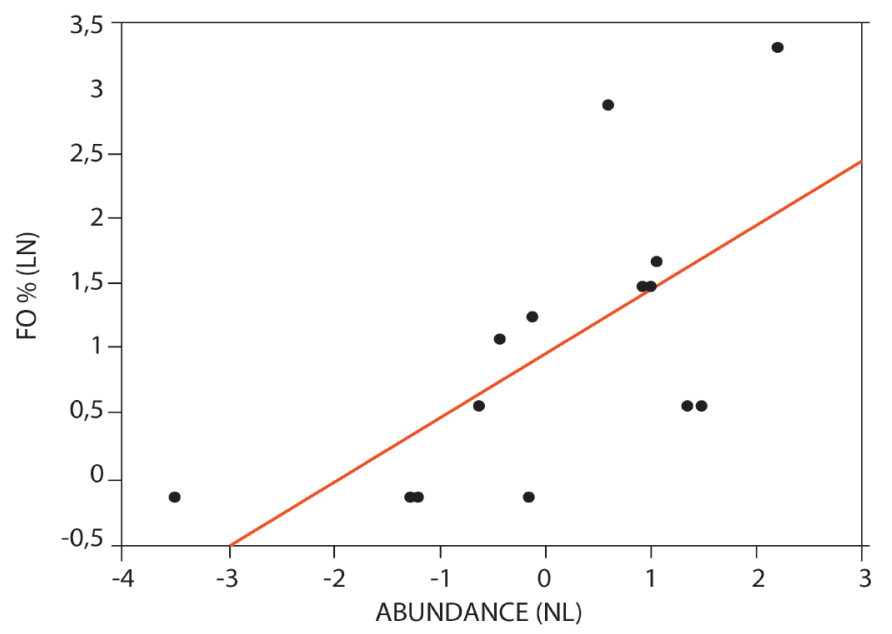

Figure 2. A) Linear regression between Natural Logarithm of FO \% and Natural Logarithm of jaguar prey abundance $\left(r^{2}=43 \% ; F=0.0104\right)$. B) Linear regression between FO $\%$ and puma prey abundance $\left(r^{2}=44 \% ; F=0.0179\right)$. 


\begin{tabular}{|c|c|c|c|c|c|c|c|c|c|}
\hline \multirow[b]{3}{*}{ Species } & \multirow[b]{3}{*}{ Weight (kg) } & \multicolumn{4}{|c|}{ All scats } & \multicolumn{4}{|c|}{ Scats with tracks } \\
\hline & & \multicolumn{2}{|c|}{ Jaguar } & \multicolumn{2}{|c|}{ Puma } & \multicolumn{2}{|c|}{ Jaguar } & \multicolumn{2}{|c|}{ Puma } \\
\hline & & No & RBC \% & No & RBC \% & No & RBC \% & No & RBC \% \\
\hline Tayassu pecari & 35 & 31 & 37 & 4 & 5 & 13 & 33 & 3 & 7 \\
\hline Pecari tajacu & 26 & 20 & 22 & 11 & 11 & 5 & 11 & 5 & 10 \\
\hline Tapirus terrestris & 239 & 2 & 8 & & & 2 & 16 & & \\
\hline Mazama americana & 36 & 5 & 6 & 5 & 6 & 2 & 5 & 2 & 5 \\
\hline Dasyprocta spp. & 5 & 6 & 5 & 5 & 4 & 4 & 7 & 1 & 2 \\
\hline Cuniculus paca & 5 & 5 & 4 & 24 & 18 & 1 & 2 & 13 & 20 \\
\hline Nasua nasua & 5 & 4 & 3 & 10 & 8 & 3 & 5 & 6 & 9 \\
\hline Hydrochoerus hydrochaeris & 50 & 2 & 3 & & & 1 & 3 & & \\
\hline Sciurus spadiceus & 1 & 3 & 2 & 7 & 5 & 2 & 3 & 3 & 4 \\
\hline Ateles chamek & 8 & 2 & 2 & 3 & 2 & 2 & 4 & 1 & 2 \\
\hline Sylvilagus brasiliensis & 4 & 2 & 2 & 10 & 8 & 1 & 2 & 5 & 7 \\
\hline Didelphis marsupialis & 1 & 2 & 2 & 10 & 7 & 1 & 2 & 8 & 11 \\
\hline Myrmecophaga tridactyla & 22 & 1 & 1 & & & 1 & 2 & & \\
\hline Procyon cancrivorus & 5 & 1 & 1 & 8 & 6 & 1 & 2 & 3 & 5 \\
\hline Eira barbara & 5 & 1 & 1 & 4 & 3 & 1 & 2 & 3 & 5 \\
\hline Potos flavus & 3 & 1 & 1 & 1 & 1 & & & 1 & 1 \\
\hline Echimydae & 2 & 1 & 1 & 12 & 9 & 1 & 2 & 6 & 9 \\
\hline Ameiva sp. & 1 & 1 & 1 & 3 & 2 & 1 & 2 & 1 & 1 \\
\hline Caiman yacare & 34 & & & 1 & 1 & & & & \\
\hline Alouatta sara & 7 & & & 1 & 1 & & & & \\
\hline Tamandua tetradactyla & 6 & & & 1 & 1 & & & 1 & 2 \\
\hline Bradypus variegatus & 4 & & & 1 & 1 & & & 1 & 1 \\
\hline Galictis vittata & 2 & & & 3 & 2 & & & & \\
\hline Total occurrences & & 90 & & 124 & & 42 & & 63 & \\
\hline Total items & & 18 & & 23 & & 17 & & 17 & \\
\hline Total scats & & 66 & & 56 & & 20 & & 22 & \\
\hline
\end{tabular}

jaguars preyed mostly on large to medium sized prey, which mirrors many previous studies (Table 4). From an energy perspective it is preferable to hunt larger prey (Aranda 2002), and previous studies have suggested that peccary hunting by jaguars may be the result of preferential adaptive predation towards these ungulates, since, as these animals are dangerous and difficult to hunt, physical skills are required to kill them quickly (Schaller et al. 1984; Aranda 2002).

The collared peccary (Pecari tajacu) was the second most important prey in the jaguar diet at our study site. Many studies have reported this species as the most consumed by this feline, with only one study reporting the white-lipped peccary (Tayassu pecari) as the prey with the highest FO \% and BRC \% (Table 4), as in our study. Collared peccaries form small groups and are relatively quiet, while white-lipped peccaries form large and noisy herds that may attract the jaguar's attention (Garla et al. 2001). However, Polisar et al. (2003)1 suggest that jaguars consume both peccary species according to their availability. Estimated white-lipped peccary relative abundance at our study site was high at the time of the dietary study, with 9.1 independent events/100 camera trap nights (Ayala and Viscarra 2009), reflected in a population density of 10.74 individuals/100 km², with an average of 3.9 white-lipped peccary herds encountered every $10 \mathrm{~km}$ of transect (Romero-Valenzuela 2008). Thus, jaguars were probably responding to a high availability of this tropical ungulate.

Contrary to these results, studies in Central America have shown that medium-sized prey contribute more to jaguar diet (Table 4), again apparently responding to prey abundance, with jaguars smaller than in South America (Hernández 2008).

Across their range, pumas consume significantly more rodents than jaguars (Nuñez et al. 2000) and specialize on medium to small prey (Table 4). Our results also showed a preference for medium to small prey, especially rodents, 


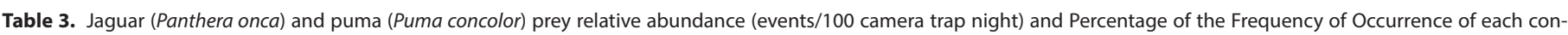
sumed prey (FO \%).

\begin{tabular}{|c|c|c|c|c|c|}
\hline & & & Jaguar & & Puma \\
\hline Prey & $\begin{array}{l}\text { Abundance within } \\
\text { the study area }\end{array}$ & FO \% (All scats) & FO \% (Scats with footprints) & FO \% (All scats) & FO \% (Scats with footprints) \\
\hline Tayassu pecari & 9.10 & 28 & 27 & 2 & 4 \\
\hline Pecari tajacu & 1.84 & 18 & 10 & 7 & 6 \\
\hline Dasyprocta spp. & 2.86 & 5 & 8 & 3 & 1 \\
\hline Mazama americana & 2.75 & 5 & 4 & 3 & 3 \\
\hline Cuniculus paca & 2,51 & 5 & 2 & 14 & 16 \\
\hline Nasua nasua & 0.90 & 4 & 6 & 6 & 8 \\
\hline Sciurus spadiceus & 0.66 & 3 & 4 & 4 & 4 \\
\hline Tapirus terrestris & 3.87 & 2 & 4 & & \\
\hline Hydrochoerus hydrochaeris & 0.53 & 2 & 2 & & \\
\hline Sylvilagus brasiliensis & 14.79 & 2 & 2 & 6 & 6 \\
\hline Didelphis marsupialis & 4.42 & 2 & 2 & 6 & 10 \\
\hline Myrmecophaga tridactyla & 0.28 & 1 & 2 & & \\
\hline Procyon cancrivorus & 0.87 & 1 & 2 & 5 & 4 \\
\hline Eira barbara & 0.30 & 1 & 2 & 2 & 4 \\
\hline Potos flavus & 0.03 & 1 & & 1 & 1 \\
\hline Tamandua tetradactyla & & & & 1 & 1 \\
\hline
\end{tabular}

with the paca (Cuniculus paca) the most consumed species in the puma's diet in both FO \% and BRC \%. Although this species is reported as part of the puma diet in several studies (Emmons 1987; Novack et al. 2005; Caselli de
Azevedo 2008; Hernández 2008), none record it as the main species in the puma diet. Rather, agoutis (Dasyprocta spp.) are reported as more frequently consumed by puma in previous studies (Table 4). At our study

Table 4. Jaguar (Panthera onca) and puma (Puma concolor) diet reported in this study compared to previous studies across the jaguar and puma range.

\begin{tabular}{|c|c|c|c|c|c|c|c|c|c|}
\hline \multirow[b]{2}{*}{ Studies } & \multirow[b]{2}{*}{$\begin{array}{c}\text { Prey size } \\
\text { preferences }\end{array}$} & \multicolumn{2}{|l|}{ Jaguar } & \multicolumn{5}{|c|}{ Puma } & \multirow[b]{2}{*}{ RBC \% } \\
\hline & & Mostly consumed prey & $\begin{array}{c}\text { FO } \\
\%\end{array}$ & $\begin{array}{l}\text { Prey with greate conti- } \\
\text { bution to RBC }\end{array}$ & $\begin{array}{c}\text { RBC } \\
\%\end{array}$ & Mostly consumed prey & FO $\%$ & $\begin{array}{l}\text { Prey with greate conti- } \\
\text { bution to RBC }\end{array}$ & \\
\hline $\begin{array}{l}\text { Data form this study (all scats) } \\
\text { (Bolivia) }\end{array}$ & large to medium & Tayassu pecari & 28 & Tayassu pecari & 37 & Cuniculus paca & 14 & Cuniculus paca & 18 \\
\hline $\begin{array}{l}\text { Data form this study (scats with } \\
\text { footprints; Bolivia) }\end{array}$ & large to medium & Tayassu pecari & 27 & Tayassu pecari & 33 & Cuniculus paca & 16 & Cuniculus paca & 20 \\
\hline Emmons 1987 (Perú) & large to medium & tortoise/turtles & 33 & & & Dasyprocta variegata & 33 & & \\
\hline $\begin{array}{l}\text { Chinchilla } 1997 \text { (wet season; } \\
\text { Costa Rica) }\end{array}$ & large to medium & Iguana iguana & 37 & Tayassu pecari & 57 & Proechimys semispinosus & 29 & Ateles geoffroyi & 32 \\
\hline $\begin{array}{l}\text { Chinchilla } 1997 \text { (dry season; } \\
\text { Costa Rica) }\end{array}$ & large to medium & Choleopus hoffmani & 21 & Tayassu pecari & 55 & Mazama americana & 25 & Mazama americana & 66 \\
\hline Taber et al. 1997 (Paraguay) & large to medium & Mazama gouazoubira & 23 & Mazama gouazoubira & 37 & Mazama gouazoubira & 12 & Mazama gouazoubira & 24 \\
\hline Nuñez 2000 (México) & large to medium & Odocoileus virginianus & 52 & Odocoileus virginianus & 54 & Odocoileus virginianus & 55 & Odocoileus virginianus & 66 \\
\hline Garla 2001 (Brasil) & large to medium & Tayassu pecari & 21 & Tayassu pecari & 26 & & & & \\
\hline Polisar et al. 2003 (Venezuela) & large to medium & Pecari tajacu & 26 & & & $\begin{array}{l}\text { H. hydrochaeris } \\
\text { /O. virginianus }\end{array}$ & $\begin{array}{r}20 \\
/ 10\end{array}$ & & \\
\hline Scognamillo 2003 (Venezuela) & large to medium & Pecaritajacu & 26 & Pecari tajacu & 27 & Pecari tajacu (juvenil) & 12 & Hydrochoerus hydrochaeris & 21 \\
\hline Novack et al. 2005 (Guatemala) & medium & Dasypus novemcinctus & 47 & Dasypus novemcinctus & 32 & Dasyprocta punctata & 26 & Dasyprocta punctata & 16 \\
\hline Weckel et al. 2006 (Belize) & large to medium & Dasypus novemcinctus & 33 & & & & & & \\
\hline Caselli and Murray 2007 (Brasil) & large to medium & Hydrochoerus hydrochaeris & 14 & Hydrochoerus hydrochaeris & 24 & & & & \\
\hline Caselli de Azevedo 2008 (Brasil) & large to medium & Pecaritajacu & 27 & Pecaritajacu & 32 & Dasyprocta azarae & 21 & Mazama sp. & 20 \\
\hline Hernández 2008 (México) & medium & Pecari tajacu & 54 & Pecari tajacu & 27 & Venados & 38 & Venados & 45 \\
\hline Gómez 2010 (México) & large to medium & Dasypus novemcinctus & 38 & Dasypus novemcinctus & 32 & Dasypus novemcinctus & 55 & Dasypus novemcinctus & 49 \\
\hline Rosas 2003 (México) & large to medium & & & & & Ovis canadensis & 40 & Ovis canadensis & 47 \\
\hline $\begin{array}{l}\text { De la Torre and De la Riva } 2009 \\
\text { (México) }\end{array}$ & large to medium & & & & & Odocoileus virginianus & 42 & Odocoileus virginianus & 36 \\
\hline
\end{tabular}


site, Cuniculus and Dasyprocta showed a similar relative abundance (Table 3). Pacas are significantly larger than agoutis (Emmons and Feer 1999). Puma activity patterns within our study area are cathemeral, with intermittent activities during the day and at night, but the majority of camera trap photographic records at night (Gómez et al. 2005; Ayala et al. in press). This suggests another possible selection factor, because Cuniculus is nocturnal, whilst Dasyprocta is diurnal (Avila-Nájera et al. 2016; Ayala and Viscarra 2009; Briones-Salas et al. 2015).

Nevertheless, other studies reported that larger prey, especially deer, contribute a higher percentage of puma diet in terms of BRC \%, even in areas where they are sympatric with the jaguar (Table 4). Comparative studies of puma diet across the range revealed wide variation in the frequency of occurrence of deer from 37.3 in México, 6.4 in Brazil, to zero in Perú (MacBride 1976; Emmons 1987; Iriarte et al. 1990; (rawshaw and Quigley 2002). Thus, the puma maybe opportunistic (Hernández 2008) and as deer abundance decreases, they change their diet to more abundant prey types (Ackerman et al. 1986; Iriarte et al. 1990; Aranda 2000; Pacheco et al. 2004). A predictive model for puma diet indicates the ability to change their habits and hunt small prey when they are very abundant (Ackerman et al. 1986).

Within our study area, the only species of deer is the red brocket (Mazama americana), found at a similar relative abundance to the paca (Ayala and Viscarra 2009; Table 3), but is consumed considerably less. Some authors attribute the consumption of medium sized prey by pumas to their sympatry with jaguars, since in areas where the two felines do not coexist, pumas hunt more large prey, especially deer (Iriarte et al. 1990; Laundré and Hernández 2002; Rosas et al. 2003; De la Torre and De la Riva 2009).

At our study site, there was a low trophic niche overlap between the two cats: although they share most prey species, the jaguar consumes more large prey and the puma more medium-sized prey. Other studies have reported greater (0.84) and lower (0.33) trophic niche overlaps between the two cats (Table 5). Taber et al. (1997) indicate that despite the similarity in diet of jaguar and puma, in general, there is no evidence of competition, and Nuñez et al. (2000) conclude that, as in our study, both felines consume similar prey, but in different proportions.

We found that the jaguar is more selective in its diet and the puma more generalist. Similar results were observed in South America (Table 5), but a different pattern is observed in Central America (Table 5), where pumas tend to be more selective in their prey and jaguars more generalist. In conclusion, prey selection for jaguar and puma largely depends on prey abundance. However, it may also be related to activity patterns, since jaguars are more active during the day (Ayala et al. in press), as are both peccaries species that are their main prey. Jaguars typically taking larger prey than pumas, suggesting adaptive predation according to the body shape of both cats.
Table 5. Overlap and trophic niche width of jaguar and puma reported in this study and other studies in the Neotropics

\begin{tabular}{|c|c|c|c|}
\hline Studies & $\begin{array}{l}\text { Trophic niche } \\
\text { overlap }\end{array}$ & $\begin{array}{c}\text { Niche width } \\
\text { for jaguar }\end{array}$ & $\begin{array}{l}\text { Niche width } \\
\text { for puma }\end{array}$ \\
\hline Data form this study (all scats; Bolivia) & 0.46 & 0.28 & 0.56 \\
\hline \multicolumn{4}{|l|}{ Data form this study (scats with } \\
\hline footprints; Bolivia) & 0.44 & 0.42 & 0.58 \\
\hline Taber et al. 1997 (Paraguay) & 0.65 & & \\
\hline Nuñez 2000 (México) & 0.84 & 0.50 & 0.38 \\
\hline Scognamillo 2003 (Venezuela) & 0.70 & 0.32 & 0.85 \\
\hline Novack et al. 2005 (Guatemala) & 0.33 & & \\
\hline Caselli de Azevedo 2008 (Brasil) & 0.56 & 0.35 & 0.47 \\
\hline Hernández 2008 (México) & 0.51 & 0.80 & 0.69 \\
\hline Gómez 2010 (México) & 0.83 & 0.64 & 0.13 \\
\hline
\end{tabular}

Finally, our study occurred within neighboring protected areas and indigenous territories, and the information herein significantly improves our knowledge about the ecology of these apex predators that are conservation objectives for the national parks. Subsistence hunting by Indigenous People is permitted within the Natural Area of Integrated Management portion of the Madidi protected area and the Pilón Lajas Biosphere Reserve, with both peccaries and the paca popular targets, coinciding with the most consumed prey for both cats (CSF 2011; CIPTA and WCS 2017). Our information stresses the importance of monitoring and managing subsistence hunting into the future, so the availability of prey for both cats and the indigenous communities is not affected. Protected areas aim to conserve biodiversity, including predator-prey dynamics as an indicator of a healthy ecosystem. Therefore, continued monitoring of the population dynamics of jaguars, pumas and their prey, will help evaluate ecosystem health. This will facilitate decision-making to ensure the conservation and protection of the natural heritage of the country.

\section{Acknowledgements}

We thank the Wildlife Conservation Society, the Liz Claibourne and Art Ortenberg Fund, and Gordon and Betty Moore Foundation for funding this study. Special thanks to the Bolivian Fauna Collection, Noel Kempff Mercado Natural History Museum and La Paz Municipal Zoo Vesti Pakos for donating hairs to facilitate species identification. We also thank J. Vargas for allowing me to review rodent specimens at the Bolivian Fauna Collection, as well as J. Aparicio and $\mathrm{M}$. Ocampo for help in reptile identification. This work would not have been possible without the collaboration of our field guides J. Durán and J. Ocampo who helped in sample collection and identification.

\section{Literature Cited}

Ackerman, B. B., F. G. Lindzey, And T. P. Hemker. 1984. Cougar food habits in southern Utah. The Journal of Wildlife Management 48:147-155. 
Ackerman, B. B., F. G. Lindzey, And T. P. Hemker. 1986. Predictive energetics model for cougars. Pp. 333-352, in Cats of the world: biology, conservation, and management (Miller, S. D., and D. D. Everet, eds.). National Wildlife Federation. Washington, U.S.A.

Aranda, M. 2000. Huellas y Otros Rastros de los Mamíferos Grandes y Medianos de México. Instituto de Ecología A. C. Xalapa, Veracruz.

Aranda, M. 2002. Importancia de los pecaríes para la conservación del jaguar en México. Pp. 101-105, in El Jaguar en el Nuevo Milenio (Medellín R., C. Equihua, C. Chetkiewicz, P. Crawshaw, A. Rabinowitz, K. Redford, J. Robinson, E. Sanderson, and A. Taber, eds.). Fondo de Cultura Economica. Ciudad de México, México.

Aranda, M., and V. Sánchez-Cordero. 1996. Prey spectra of jaguar (Panthera onca) and puma (Puma concolor) in tropical forests of Mexico. Studies on Neotropical Fauna and Environment 31:65-67.

Ávila-Nájera, D. M., C. Chávez, M. A. Lazcano-Barrero, G. D Mendoza, And S. Perez-Elizalde. 2016. Traslape en patrones de actividad entre grandes felinos y sus principales presas en el norte de Quintana Roo, México. Therya 7:439-448.

Ayala, G., ANd M. Viscarra. 2009. Estimando la densidad de jaguar y la abundancia relativa de mamíferos medianos y grandes en el Parque Nacional Madidi y la Reserva Pilón Lajas, Bolivia. Unpublished report. Wildlife Conservation Society. La Paz, Bolivia.

Briones-Salas, M., I. Lira-Torres, R. Carrera-Treviño, and G. SÁncheZ-RojAs. 2015. Relative abundance and activity patterns of wild felids in Chimalapas rainforest, Oaxaca, Mexico. Therya 7:123-134.

Caselui de Azevedo, F. C. 2008. Food habits and livestock depredation of sympatric jaguars and pumas in the Iguacu National Park area, south Brazil. Biotropica 40:494-500.

Caselli de Azevedo, F. C., And D. L. Murray. 2007. Spatial organization and food habits of jaguars (Panthera onca) in a floodplain forest. Biological Conservation 137:391-402.

Chame, M. 2003. Terrestrial mammal scats: a morphometric summary and description. Memórias do Instituto Oswaldo Cruz 98:71-94.

Chehébar, C., and S. Martín. 1989. Guía para el reconocimiento microscópico de los pelos de los mamíferos de la Patagonia. Doñana Acta Vertebrata 16:247-291.

Chinchilla, F. A. 1997. La dieta del jaguar (Panthera onca), el puma (Felis concolor) y el manigordo (Felis pardalis) (Carnivora: Felidae) en el Parque Nacional Corcovado, Costa Rica. Revista de Biología Tropical 45:1223-1229.

Chumacero, L. M. G., And A. Sainoz. 2010. Mamíferos-depredadores ¿controlan las densidades poblacionales de los mamıferos-presa? Universidad Autónoma Metropolitana-Iztapalapa. Departamento de Biología, División de CBS. ContactoS 76:5-9.

Crawshaw, P. G., AND H. B. Quigley. 2002. Hábitos alimentarios del jaguar y el puma en el Pantanal, Brasil, con implicaciones para su manejo y conservación. Pp. 223-235, in El Jaguar en el Nuevo Milenio (Medellín R., C. Equihua, C. Chetkiewicz, P. Crawshaw, A. Rabinowitz, K. Redford, J. Robinson, E. Sanderson, and A. Taber, eds.). Fondo de Cultura Economica. Ciudad de México, México.

Consejo Indígena del Pueblo Indígena Tacana and Wildlife Conservation Society (CIPTA and WCS). 2017. Caza de subsistencia en el territorio indígena Tacana. La Paz, Bolivia.
Conservation Strategy Fund (CSF). 2011. Reglas para la cacería en comunidades indígenas de la Reserva de la Biósfera y Tierra Comunitaria de Origen Pilón Lajas: Un análisis desde la economía experimental. La Paz, Bolivia.

De Angelo, C., A. Paviolo, Y. Di Blanco, And M. Di Bitettı. 2017. Guía para la Identificación de Huellas de Mamíferos de Misiones y otras Áreas del Subtrópico de Argentina. Ediciones del Subtrópico, Fundación ProYungas. Yungas, Argentina.

De la Quintana, D. 2005. Diversidad florística y estructura de una parcela permanente en un bosque amazónico preandino del sector del Río Hondo, Área Natural de Manejo Integrado Madidi (La Paz, Bolivia). Ecología en Bolivia 40:418-442.

De la Torre, J. A., and G. De la Riva. 2009. Food habits of pumas (Puma concolor) in a semiarid region of central Mexico. Mastozoología Neotropical 16:211-216.

Emmons, L. H. 1987. Comparative feeding ecology of felids in a neotropical rainforest. Behavioral Ecology and Sociobiology 20:271-283.

Emmons, L. H., and F. Feer. 1999. Mamíferos de los Bosques Húmedos de América Tropical. Fundación Amigos de la Naturaleza. Santa Cruz de la Sierra, Bolivia.

Farrell, L. E., J. Roman, and M. E. Sunquist. 2000. Dietary separation of sympatric carnivores identified by molecular analysis of scats. Molecular Ecology 9:1583-1590.

Fernández, G. J., AND S. M. Rossı. 1998. Medullar type and cuticular scale patterns of hairs of rodents and small marsupials from the Monte Scrubland (San Luis Province, Argentina). Mastozoología Neotropical 5:109-116.

Garla, R. C., E. Z. Setz, and N. Gobbi. 2001. Jaguar (Panthera onca) food habits in Atlantic rain forest of southeastern Brazil. Biotropica 33:691-696.

GaU, R. J., R. Mulders, T. Lamb, And L. GunN. 2001. Cougars (Puma concolor) in the Northwest Territories and Wood Buffalo National Park. Arctic 54:185-187.

Gómez, H., R. B. Wallace, G. Ayala, And R. Tejada. 2005. Dry season activity periods of some Amazonian mammals. Studies on Neotropical Fauna and Environment 40:91-95.

Gómez, Y. 2010. Nicho Trófico de Jaguar y Puma en la Reserva Natural Sierra Nanchititla, México. Masters Thesis. Universidad Autónoma de Baja California. Mexicalli. Baja California, México. Hernández, C. G. E. 2008. Dieta, uso de hábitat y patrones de actividad del puma (Puma concolor) y el jaguar (Panthera onca) en la Selva Maya, Centroamérica. Revista Mexicana de Mastozoología 12:113-130.

Identidad Madid and SERNAP. 2019. Informe de la Expedición Científica Identidad Madidi 2016. Relevamientos de Biodiversidad en el Parque Nacional y Área Natural de Manejo Integrado Madidi. La Paz, Bolivia.

Iriarte, J. A., W. L. Franklin, W. E. Johnson, and K. H. Redford. 1990. Biogeographic variation of food habits and body size of the America puma. Oecologia 85:185-190.

Jorgensen, P. M., M. J. Macía, A. Fuentes, S. G. Beck, M. Kessler, N. Paniagua, R. Seidel, C. Maldonado, A. Araujo-Murakami, L. Cayola, T. Consiglio, T. J. Killeen, W. H. Cabrera, F. Bascopé, D. De la Quintana, T. Miranda, F. Canqui, and V. Cardona-Peña. 2005. Lista anotada de las plantas vasculares registradas en la región de Madidi. Ecología en Bolivia 40:70-169.

Kıtchener, A. 1991. The Natural History of the Wild Cats. Comstock Pub. Associates. New York, U.S.A. 
Laundré, J. W., ANd L. Hernández. 2003. Winter hunting habitat of pumas (Puma concolor) in northwestern Utah and southern Idaho, USA. Wildlife Biology 9:123-129.

Leite R., R. Boulhosa, F. Galvao, and L. Cullen. 2002. Conservación del jaguar en las áreas protegidas del bosque Atlántico de la costa del Brasil. Pp 25-41, in El Jaguar en el Nuevo Milenio (Medellín R., C. Equihua, C. Chetkiewicz, P. Crawshaw, A. Rabinowitz, K. Redford, J. Robinson, E. Sanderson, and A. Taber eds.). S.L. Fondo de Cultura Economica. Fondo de Cultura Economica. Ciudad de México, México.

Levins, R. 1968. Evolution in Changing Environments. Princeton Univ. Press, Princeton. New Jersey, U.S.A.

Maxit, I. E. 2001. Prey Use by Sympatric Puma and Jaguar in the Venezuelan Llanos. Masters Thesis, Universidad de Florida, U.S.A.

McBride, R. T. 1976. The Status and Ecology of the Mountain Lion Felis concolor stanleyana, of the Texas-Mexico Border. Doctoral Thesis, Sul Ross State University, Alpine, U.S.A.

Navarro, G., and M. Maldonado. 2002. Geografía Ecológica de Bolivia: Vegetación y Ambientes Acuáticos. Centro de Ecología Simón I. Patiño. Cochabamba, Bolivia.

Novack, A. J., M. B. Main, M. E. Sunquist, and R. F. Labisky. 2005. Foraging ecology of jaguar (Panthera onca) and puma (Puma concolor) in hunted and non-hunted sites within the Maya Biosphere Reserve, Guatemala. Journal of Zoology 267:167-178.

Núñez, R., B. Miller, ANd F. Lindzey. 2000. Food habits of jaguars and pumas in Jalisco, Mexico. Journal of Zoology 252:373-379.

Pacheco, L. F., A. Lucero, and M. Villca. 2004. Dieta del puma (Puma concolor) en el Parque Nacional Sajama, Bolivia y su conflicto con la ganadería. Ecología en Bolivia 39:75-83.

Paniagua-Zambrana, N. Y. 2005. Diversidad, densidad, distribución y uso de las palmas en la región del Madidi, noreste del departamento de La Paz (Bolivia). Ecología en Bolivia 40:265-280.

Paviolo, A. J. 2010. Densidad de yaguareté (Panthera onca) en la selva paranaense: su relación con la disponibilidad de presas, presión de caza y coexistencia con el puma (Puma concolor). Mastozoología Neotropical 17:397-398.

Pianka, E. R. 1973. The structure of lizard communities. Annual Review of Ecology and Systematics 4:53-74.

Polisar, J., I. Maxit, D. Scognamillo, L. Farrell, M. E. Sunquist, AND J. F. EISEnBerg. 2003. Jaguars, pumas, their prey base, and cattle ranching: ecological interpretations of a management problem. Biological Conservation 109:297-310.

Quadros, J., AND E. L. D. A. Monteiro-Filho. 2006. Revisão conceitual, padrões microestruturais e proposta nomenclatória para os pêlos-guarda de mamíferos brasileiros. Revista Brasileira de Zoologia 23:279-292.

Ramalho, E. E., and W. E. Magnusson. 2009. Uso do habitat por onça-pintada (Panthera onca) no entorno de lagos de várzea, Reserva de Desenvolvimento Sustentável Mamirauá, AM, Brasil. Scientific Magazine UAKARI 4:33-39.

Ríos-Uzeda, B., R. B. Wallace, H. Aranibar, and C. Veitch. 2001. Evaluación de mamíferos medianos y grandes en el bosque semideciduo del alto Tuichi (PN y ANMI Madidi, Depto. La Paz). Ecología en Bolivia 36:31-38.

Romero-Valenzuela, D. 2008. Estimación de la Densidad Poblacional del Chancho de Labios Blancos (Tayassu pecari) en el Valle del Río Hondo, Parque Nacional y Área Natural de
Manejo Integrado (Bolivia). Tesis de Licenciatura Universidad Mayor de San Andrés. La Paz, Bolivia.

Rosas, O. C., R. Valdez, L. C. Bender, and D. Daniel. 2003. Food habits of pumas in northwestern Sonora, Mexico. Wildlife Society Bulletin 31:528-535.

SAS Institute Inc. 2007. JMP user's guide. arXiv:1004.3173.

Schaller, G. B., AND P. G. Crawshaw JR. 1980. Movement patterns of jaguar. Biotropica 12:161-168.

Schaller, G. B., H. B. Quigley, and P. G. Crawshaw. 1984. Biological investigations in the Pantanal, Mato Grosso, Brazil. National Geographic Society Research Reports 17:777-792.

Scognamillo, D., I. E. Maxit, M. Sunquist, and J. Polisar. 2003. Coexistence of jaguar (Panthera onca) and puma (Puma concolor) in a mosaic landscape in the Venezuelan Ilanos. Journal of Zoology 259:269-279.

Seymour, K. L. 1989. Panthera onca. Mammalian Species 340:1-9.

Short, H. L. 1978. Analysis of cuticular scales on hairs using the scanning electron microscope. Journal of Mammalogy 59:261-268.

Sunquist, M. E., ANd F. C. Sunquist. 1989. Ecological constraints on predation by large felids. Pp. 283-301 in Carnivore Behaviour, Ecology and Evolution (Gittleman, J. L., ed.). Springer Science. Ithaca, U.S.A.

Taber, A. B., A. J. Novaro, N. Neris, And F. H. Colman. 1997. The food habits of sympatric jaguar and puma in the Paraguayan Chaco. Biotropica 29:204-213.

Tavera, G. 2006. Patrones Cuniculares y Medulares de Pelos de Cinco Especies de Roedores Altoandinos del Departamento de Cochabamba. Tesis de Licenciatura, Carrera de Biología, Universidad Mayor de San Simón. Cochabamba, Bolivia.

Vázquez, D. E., P. G. Perovic, and A. A. de Olsen. 2000. Patrones cuticulares y medulares de pelos de mamíferos del noroeste argentino (Carnivora y Artiodactyla). Mastozoología Neotropical. 7:131-147.

Viscarra, M., C. Flores-Turdera, And G. Ayala. 2010. Catálogo de Pelos Guardia de Mamíferos Medianos y Grandes. Wildlife Conservation Society. La Paz, Bolivia

Wallace, R. B., H. Gomez, G. Ayala, and F. Espinoza. 2003. Camera trapping for jaguar (Panthera onca) in the Tuichi Valley, Bolivia. Mastozoología Neotropical 10:133-139.

Weckel, M., W. Giuliano, ANd S. Silver. 2006. Cockscomb revisited: Jaguar diet in the Cockscomb Basin Wildlife Sanctuary, Belize. Biotropica 38:687-690.

Zafarina, Z., And S. Panneerchelvam. 2009. Analysis of hair samples using microscopical and molecular techniques to ascertain claims of rare animal species. The Malaysian Journal of Medical Sciences 16:35.

Associated editor: Rafael Reyna

Submitted: May 5, 2020; Reviewed: June 26, 2020;

Accepted: July 7, 2020; Published on line: November 17, 2020. 
DIET OF LARGE FELIDS IN BOLIVIA

84 TTHERYA Vol. 12 (1): 75-83 